Tyndale Bulletin 68.2 (2017) 161-184

\title{
THE CHALLENGE OF THE CANAANITES
}

\author{
William Ford \\ (WFord@BelfastBibleCollege.com)
}

\begin{abstract}
Summary
The negative biblical portrayal of the Canaanites appears to contrast sharply with the wider portrayal of YHWH's relationship with humanity and with Israel in particular, raising a challenge for reading these parts of the Bible as Scripture. This article considers this portrayal by drawing together key biblical references to the Canaanites into two sections: Canaanites as a whole, and as individuals. Four potential images are evaluated as possible summaries of the biblical portrayal of the Canaanites: sinners, danger, warning, and challenge, with the last being the most appropriate. The Canaanites' proximity to Israel, both geographic and moral, raises both a negative and positive challenge. Israelites can become Canaanites and vice versa, depending on their response to $\mathrm{YHWH}$.
\end{abstract}

\section{Introduction}

The patriarchal promises, first given to Abram in Genesis 12, are an important part of the biblical story of YHWH's overall plan of salvation. They look back to YHWH's original blessings for humanity, contain the theme of the Pentateuch, underlie the ongoing story of the Old Testament through its highs and lows, and lead into the New Testament, where the final element of blessing for all families on earth is fulfilled through Christ.

One element of these promises is land, specifically the land of Canaan (Gen. 12:5), which is explicitly included in the promises (v. 7). However, between these verses comes the seeming aside that the 
Canaanites were then in the land (v. 6b). ${ }^{1}$ At this point, it is unclear how the land of the Canaanites is to become the land of Abram's descendants and what this will mean for the Canaanites themselves. As the biblical story unfolds and Israel come out of Egypt, more clarity is given. YHWH tells Israel that the Canaanites must be destroyed from the land. ${ }^{2}$

These divine commands and Israel's execution of them in Joshua are arguably one of the most difficult issues when reading the Bible as Scripture. The inherent difficulty of the divinely commanded violence is exacerbated by the fact that this is not in an obscure part of the Bible, but rather linked to the promises and YHWH's plan of salvation. For Israel (and the world) to receive this blessing, the Canaanites need to receive the opposite of blessing. This biblical portrayal of the Canaanites seems to be wholly negative and thus in conflict with the wider biblical portrayal of God and his salvific relationship with humanity. Understanding how these two portrayals interrelate could be described as the challenge of the Canaanites for reading the Bible as scripture. $^{3}$

1 A similar phase comes in 13:7 before the promise of land is expanded in vv. 14-17. The term 'Canaanites' here refers to the inhabitants of the land as a whole, and this article will use it in this general sense as a shorthand for the nations in Canaan who are the object of the divine commands. Other biblical passages contain more detailed lists of nations in Canaan. For further information see Philip D. Stern, The Biblical HEREM: A Window on Israel's Religious Experience (Atlanta: Scholars Press, 1991), 89-103.

2 E.g. Exod. 23:23; Deut. 7:1-5,24; 12:30; 20:16-17. There are other verbs used in the commands which do not sound quite as problematic as destroy, suggesting the idea of expulsion (e.g. Exod. 23:28; 34:11; Lev. 18:24-25; Num. 33:52,55; Deut. 9:4-5; $18: 12$ ). At this point, the more difficult concept of 'destroy' is being used as a summary. See 2.3.c for more discussion of this term.

3 There are a number of recent works that engage with the theological issue of the Canaanites in whole or part. These include Michael Bergman et al., ed., Divine Evil? The Moral Character of the God of Abraham ed. (Oxford: OUP, 2011), chs 2, 3, 5, 8, 9 and 10; Paul Copan and Matthew Flannagan, Did God Really Command Genocide? Coming to Terms with the Justice of God (Grand Rapids: Baker, 2014); Eryl W. Davies, The Immoral Bible: Approaches to Biblical Ethics (London: T\&T Clark, 2010); Douglas S. Earl, Reading Joshua as Christian Scripture (JTISup 2; Winona Lake: Eisenbrauns, 2010); Peter Enns, The Bible Tells Me So .... Why Defending Scripture Has Made Us Unable to Read It (New York: HarperCollins, 2014), 29-70; William Ford, 'What About the Gibeonites?', Tyndale Bulletin 66.2 (2015), 197-216; R. W. L. Moberly, 'Election and the Transformation of Herem' in The Call of Abraham: Essays on the Election of Israel in Honor of Jon D. Levenson, ed. Gary A. Anderson and Joel S. Kaminsky (Notre Dame: University of Notre Dame Press, 2013), 67-89; Eric Seibert, The Violence of Scripture: Overcoming the Old Testament's Troubling Legacy (Minneapolis: Fortress Press, 2012), 95-114; Heath A. Thomas, Holy War in the Bible: Christian Morality and an Old Testament Problem (Downers Grove: 
One part of this challenge is to understand and summarise the biblical portrayal of the Canaanites out of the various references to the Canaanites in the Bible. As might be expected, these references are most common in Genesis to Joshua, the part of the story before and during the conquest. However, the portrayal continues within the Old Testament and even briefly into the New. ${ }^{4}$

This article will consider these references in two sections: references to Canaanites as a whole, and references to individual Canaanites. ${ }^{5}$ Within these sections, four images will be considered that could be used to summarise the portrayal and role of the Canaanites: Canaanites as sinners, Canaanites as danger, Canaanites as warning, and Canaanites as challenge. ${ }^{6}$

Three limitations should be noted at this point. First, the article will not consider non-Israelite nations in general. ${ }^{7}$ The focus is on those nations in the land who are the object of the divine commands to the Israelites, and are thus the sharpest and most problematic example of non-Israel. Second, this article will not discuss historical or archaeological issues. ${ }^{8}$ The focus is on how the final, canonical form of the Bible portrays the Canaanites and the theological implications of

IVP, 2013); Arie Versluis, The Command to Exterminate the Canaanites: Deuteronomy 7 (Leiden: Brill, 2017); Stephen N. Williams, 'Could God have Commanded the Slaughter of the Canaanites?' Tyndale Bulletin 63.2 (2012), 161-78; Christopher J. H. Wright, The God I Don't Understand: Reflections on Tough Questions of Faith (Grand Rapids: Zondervan, 2008), 73-108.

4 These New Testament references are to individual Canaanites. See section 3 below.

5 This division is not exact. However, this division highlights important differences between the two portrayals.

6 The first three images have already been used in various places. For example, in three relatively recent discussions of the Canaanite issue, Wright, God, includes both 'sinners' (92-94) and 'warning' (94-96), Enns, Bible, strongly prefers 'danger' over 'sinners' (50-53), and Copan and Flannagan, Genocide, include both 'sinners' (66-68) and 'danger' (68-70).

7 For the portrayal of non-Israel more widely, see for example, Joel N. Lohr, Chosen and Unchosen: Conceptions of Election in the Pentateuch and Jewish-Christian Interpretation (Siphrut 2; Winona Lake: Eisenbrauns, 2009); Frank Anthony Spina, The Faith of the Outsider: Exclusion and Inclusion in the Biblical Story (Grand Rapids: Eerdmans, 2005).

8 For more details on this see Niels Peter Lemche, The Canaanites and Their Land: The Tradition of the Canaanites (JSOTSup110; Sheffield: Sheffield Academic Press, 1991), and Keith N. Schoville, 'Canaanites and Amorites' in A. J. Hoerth, G. L. Mattingly, and E. M. Yamauchi, Peoples of the Old Testament World (Cambridge: Lutterworth Press, 1996), 157-82. More specifically on Deuteronomy, see C. L. Crouch, The Making of Israel: Cultural Diversity in the Southern Levant and the Formation of Ethnic Identity in Deuteronomy (VTSup 162; Leiden: Brill, 2014). 
this. Third, this article will not be discussing most Canaanite references in detail, but rather focusing on the big picture. ${ }^{9}$

\section{Portrayal of Canaanites as a Whole}

The first biblical reference to the Canaanites comes before Abraham and the promise. In Genesis 9 Noah curses Canaan for the actions of Ham, saying that he will be a slave to his brothers (9:25-27). This is immediately followed by the genealogies of the three brothers $(10: 1-$ 32 ), suggesting that the focus of this passage is not on the brothers themselves, but their descendants (specifically Israel from Shem and the Canaanites from Ham and Canaan). ${ }^{10}$ This initial comparison is not favourable to the Canaanites: they are descended from the unrighteous Ham and cursed to be the slaves of the Israelites. Having said that, at this point there is no evaluation of the Canaanites themselves. For this, we must wait until they appear in the story of Abraham.

\subsection{Canaanites as Sinners}

The first evaluative reference to the Canaanites as a whole comes in Genesis 15:16, after the initial mentions of the Canaanites being in the land $(12: 6 ; 13: 17)$, and the encounters with individual Canaanites in Genesis 14. ${ }^{11}$ There, YHWH tells Abram that his descendants will return to the land in the fourth generation, 'for the sin of the Amorites is not yet complete'. ${ }^{12}$ Immediately after this, YHWH formalises his promise into a covenant: to give Abram's descendants this land of the Canaanites (15:17-21; cf. 12:7; 13:14-15). There is a strong implicit link between this covenant and the preceding verse 16. Abram's descendants will receive the land of the Canaanites and the Canaanites will lose the land because of their sin.

\footnotetext{
9 One further limitation relates to Versluis, Command. This is a recently published detailed study on the Canaanite command in Deut. 7, which includes discussion of the Canaanites in Deut. and the wider Old Testament in chapter 3. I became aware of this work as this article was being finalised. Therefore, although reference is made to it, I could not engage with its arguments in any detail.

10 This focus may provide the beginnings of an answer as to why Canaan is cursed rather than Ham. The focus is on the Canaanites rather than the individual Canaan. As a result, this passage would be an example that does not fit neatly into the division between Canaanites as a whole and as individuals.

11 On Gen. 14, see 3.1 below.

12 Here Amorites is used in a collective sense for all the nations, similar to 'Canaanites'. All biblical translations are my own.
} 
Thus, the first evaluation of the Canaanites is that they are sinners. However, they are not yet bad enough sinners to lose the land, and will not be so for 400 years. This suggests that the actions of the Canaanites make a difference to YHWH. He does not just get rid of them in order to give their land to Abram immediately. Rather, he and his descendants must wait (including a period of oppression in Egypt in v. 13) until the Canaanites have gone too far.

This image of 'Canaanites as sinners' is repeated in Deuteronomy 9:4-5, which states that it is because of the wickedness of the Canaanites that YHWH is dispossessing them of the land before Israel, before linking this to the patriarchal promise once more. As with Genesis $15: 16$, the Canaanites' sin is linked to them losing the land, this time explicitly. ${ }^{13}$

Deuteronomy 18:9-12 also speaks of YHWH driving out the nations because of their detestable practices. In contrast to the previous passages, some details are given about these practices: child sacrifice, and various forms of sorcery or divination (vv. 10-11). The focus here on religious practices detestable to YHWH is continued in other biblical passages. ${ }^{14}$ With the exception of sexual practices in Leviticus, this is the area in which the Canaanites are condemned. ${ }^{15}$ Other areas are not mentioned, for example those found in the prophetic oracles against other nations such as oppression, murder, dispossession, arrogance, and so forth. ${ }^{16}$ This is not to suggest that the Canaanites did not commit any of these acts, but rather to note that the Bible does not focus on them or call them to account for this.

The Canaanites' religious practices are not uniquely offensive to YHWH, as those of other nations are summarised similarly. ${ }^{17}$ The most negative portrayal of the Canaanites' practices is in Deuteronomy 12:31, which states that 'every abominable thing that YHWH hates they

13 The question of on what basis they were sinning or sinners (given the lack of covenant relationship with YHWH) is not addressed. However, the biblical portrayal is clear that they are, in some way, accountable to YHwH for their practices, which are evaluated as wicked or detestable.

14 E.g. Deut. 7:25; 12:31; 20:18. See Versluis, Command, 186-95 for more details.

15 Lev. 18:3,24-25; 20:20-24.

16 Isa. 13-23; Jer. 46-51; Ezek. 25-32; Amos 1-2.

17 E.g. 1 Kgs 11:5-7; Ezek. 8:14-15; 20:7-8. Cf. Lohr, Chosen, 225. With regard to the sexual sins in Lev. 18, it can be noted that these are linked to the Egyptians as well as the Canaanites (v. 3): Jacob Milgrom, Leviticus 17-22 (New York: Doubleday, 2000), 1518-19. Egypt is not mentioned in vv. 24-30, as the issue of being cast off the land is not relevant to them. 
have done for their gods. They even burn their sons and daughters in the fire to their gods.' The specific example given of child sacrifice, presumably meant to indicate the most abominable Canaanite practice (cf. Deut. 18:10), is not unique to them. ${ }^{18}$

Therefore, in summary, the Canaanites are sinners, but are not yet bad enough to lose the land. The focus is on their religious practices and these are not clearly worse than those of other nations. While the Canaanites are sinners, they are not portrayed as the worst sinners ever. ${ }^{19}$

\subsection{Canaanites as Danger}

Although the concept of judgement on the Canaanites' sins is present in the divine commands, there is another, more common reason given: that the Canaanites are a danger to Israel.

The image of 'Canaanites as danger' adds a key component to the portrayal of the Canaanites: Israel. The Old Testament is Israel's scriptures, and the outworking of YHWH's promises within the Old Testament is primarily via Israel. The major reason for the mention of the Canaanites in the Old Testament is how they and Israel interrelate. Therefore, Israel have to be taken into account when considering the portrayal of the Canaanites. To put it another way, 'Canaanites as sinners' suggests a relationship purely between YHWH and the Canaanites. 'Canaanites as danger' acknowledges the more complex relationship present involving YHWH, Israel, and the Canaanites. The divine commands about the Canaanites are not given directly to them 'you must be destroyed because of your sin/religious practices' - but rather to Israel. YHWH tells Israel either that he is destroying the Canaanites, or that Israel must destroy them, because they are a danger.

The nature of the danger is not military, although the Israelites may be tempted to think that it is. Ten of the twelve spies in Numbers 13 bring word of the strong Canaanites and their fortified cities (Num. 13:28-29,31-33). As a result, the people reject Moses and seek to return to Egypt $(14: 1-4,10)$. However, there is another perspective in the story

18 E.g. Mesha of Moab (2 Kgs 3:27) and examples from within Israel (Gen. 22:1-19; Judg. 11:30-40; 2 Kgs 16:3; 21:6). For more details on the biblical portrayal of child sacrifice, see Jon D. Levenson, The Death and Resurrection of the Beloved Son: The Transformation of Child Sacrifice in Judaism and Christianity (New Haven: Yale, 1993).

19 At one stage, Judah is even portrayed as worse than them (2 Kgs 21:9-11). See below 2.3.b. 
given by the other two spies: Caleb and Joshua. While the Canaanites are powerful, Israel can overcome them (13:30) because YHWH is with Israel (14:7-9). By fearing the Canaanites, Israel are disregarding YHWH. In the sermonic style of Deuteronomy, this fear is picked up again and rejected, contrasting Israel's fear and YHWH's provision. ${ }^{20}$ The message is clear. Do not fear the Canaanites: fear YHWH.

This is because the real danger of the Canaanites to Israel is not military but religious. If YHWH is with Israel, the Canaanites will be defeated. ${ }^{21}$ However, once this has happened, Israel are warned that they must not be tempted to follow the gods and religious practices of the Canaanites, turning away from or compromising their relationship with YHWH.22 This explicit warning occurs in almost all of the divine messages about the Canaanites before the conquest. ${ }^{23}$

Various reasons are given for this. Such behaviour is abhorrent to YHWH (Deut. 12:31; cf. 18:12; 20:18); it is a snare for Israel (Exod. 23:33; 34:12; Deut. 7:16), and it will lead to their destruction (Deut. $6: 14-15 ; 7: 4 ; 8: 19)$. This extreme danger is the context in which YHWH commands the destruction of the Canaanites. Israel must do whatever it takes to avoid idolatry. The specific outworking of this destruction focuses on two main areas: a prohibition against intermarriage, and the command to destroy their religious paraphernalia. ${ }^{24}$

20 Deut. 1:26-31;2:24-25; 3:21; 7:1,17-24; 9:1-3; 20:1.

21 Having said this, the Bible is clear that without Yнwн Israel would be defeated by the Canaanites (Num. 14:42-45; Josh. 7:1-12).

22 Deut. 7 contrasts these two dangers explicitly. The command in vv. 2-5 is to be obeyed after YHWH has handed over the 'seven nations greater and stronger than you' (v. 1). The fear of Numbers 13 is picked up in verses 17-24 with the reminder of YHWH's acts in Egypt and details of how he will defeat the stronger nations, which leads into a final warning about destroying their religious images (vv. 25-26). For a very detailed engagement with Deut. 7, see chapter 2 of Versluis, Command.

23 Exod. 23:23-33; 34:11-16; Num. 33:50-56; Deut. 7:1-5,16,25-26; 8:19-20; 12:2931; 18:9-14; 20:16-18 (cf. Josh. 23:12-16).

24 Thus, the command to wipe out (חרם, kherem) the Canaanites in Deut. 7:2 is followed by these specific examples in vv. 7:3-5, which seem to focus the intention of v. 2. On this, see Moberly, 'Election', 73-77. Avoiding intermarriage with Canaanites is linked more widely to Israel's relationship with YHWH and the promises, whether it is (implicitly) the maintenance of the chosen line (Gen. 24:1-9; 28:1-5; cf. Ezra 9:2) or (explicitly) the avoidance of idolatry (Exod. 34:16; Deut. 7:4; 1 Kgs 11:1-8; cf. Ezra $9: 14)$. The destruction of religious paraphernalia is linked to idolatry both explicitly and implicitly (Exod. 23:24, cf. v. 33; 34:13; Num. 33:52; Deut. 7:25-26; 12:2-4, cf. vv. 30-31). 
As noted above, the Canaanites are not obviously worse idolaters than other nations. The reason why they are the greatest danger to Israel, and thus the focus of these divine commands, is their location. They are the idolaters that Israel are most likely to encounter, because they are in the land that Israel are to enter. The laws of war in Deuteronomy 20 make this clear. Verses 10-14 require Israel to offer terms of peace to any hostile town. If the town agrees to surrender, they will be spared, albeit as servants. If they refuse to surrender, they will be defeated and pillaged. However, there is a clear contrast in verses 15-18 for the treatment of the towns of the nations in the land. Israel shall make no offer of peace, but rather destroy them. Once again, the reason is so that they do not teach Israel to worship their gods and sin against YHWH. This distinction is underlined in the story of the Gibeonites in Joshua 9. They deceive Israel about only one thing their location. They pretend to come from a far-off land in order to gain a covenant with Israel, which they would not get if Israel knew that they were Hivites who lived in the land. ${ }^{25}$

Comparing the two images 'sinners' and 'danger' we can note that both are accurate, as far as they go, and both are needed. Without 'sinners', 'danger' could run the risk of portraying the Canaanites as some dehumanised force of evil that has to be obliterated to protect Israel, purely because it is in the land. Without 'danger', 'sinners' could lead to viewing them as worst sinners ever, in an attempt to justify the destruction. 'Danger' is the stronger image because of the importance of Israel and the focus on this in the divine commands. However, both are linked. The Canaanites are a danger because they are the (religious) sinners in the land, and the combination of reasons is why they need to be destroyed from the land. The next image combines both of these concepts.

\subsection{Canaanites as Warning}

'Canaanites as danger' focuses on the Canaanites as different from Israel, with that difference being portrayed negatively or dangerously. However, the biblical portrayal also contains some important similarities between Israel and the Canaanites. The most obvious of these is the land. The Canaanites are the ones who were in the land before Israel. However, YHWH destroyed them from the land because

25 Ford, 'Gibeonites', 202-203. 
of their sinful practices, primarily religious. Israel have been warned of the danger of the Canaanites, the danger of following their religious practices, and the consequences of this - being destroyed from the land.

This leads to the third summary image: 'Canaanites as warning'. The Canaanites are a warning and an example to Israel, specifically concerning the link of sinful actions and the consequences for the land. Israel do not have an unalienable claim to the land as ultimately it does not belong to them, but to YHWH, who is allowing them to live there as his tenants (Lev. 25:23). YHWH gave them the land as part of the patriarchal promises, which became formalised into covenant. That covenant contained responsibilities for Israel as part of their relationship with God, prime amongst which are the requirements of loyalty to God. ${ }^{26}$ Israel cannot expect to ignore their covenant responsibilities by behaving like the Canaanites and yet still keep the land. ${ }^{27}$

In other words, the Canaanites are an example and a warning to Israel of the consequences of idolatry. If Israel act like the Canaanites then they will be treated like them.

\section{a. Pre-Conquest Warnings}

This link is made explicit in three places:

Leviticus 18 states that the Canaanites defiled the land by their sexual practices and the land vomited them out when YHWH visited its iniquity upon it (vv. 24-25,27). Verse 28 continues 'lest the land vomit you out if you defile it, just as it vomited out the nation that was before you. ${ }^{28}$

26 In one sense, the Canaanites could also be said to be YHwH's tenants in the land. Unlike Israel's covenant, the terms of the Canaanites' 'tenancy agreement' are not given. This is not surprising as the focus of the biblical text is on Israel. However, the reason for eviction from the land is their evil actions, which are detestable to the 'landlord' rather than being explained, for example, as conquest because YHWH is stronger than their gods. In the biblical picture, the land ultimately belongs to YHWH, not Israel or the Canaanites.

27 The 'temple sermon' in Jer. 7 makes the contrast particularly sharply. There are also other warnings in Deuteronomy linking idolatry and being destroyed from the land, which do not specifically mention the Canaanites (Deut. 4:25-28; 11:16-17; $30: 17-18 ; 31: 16-18)$.

28 As noted above, Lev. 18:24-30 and 20:22-24 are focused on inappropriate sexual practices rather than idolatry. However, there is a repeated contrast of following YHWH's statutes rather than the actions of the Canaanites (Lev. 18:3-5,26) which links it to the wider issue of relationship with YHWH. 
Numbers 33:55-56 warns of the consequence of Israel not driving out the nations as YHWH has commanded; that they will be hostile to Israel like thorns and barbs. Verse 56 concludes: 'And just as I planned to do to them, I will do to you.'

Deuteronomy 8:19-20 warns of the danger of following other gods; that Israel will be destroyed. Verse 20 concludes: 'Like the nations which YHWH is destroying before you, thus you will be destroyed; because you would not listen to the voice of YHWH your God.'

All three passages make a very strong link - YHWH will treat Israel as he treated the Canaanites if they act accordingly. ${ }^{29}$

The strongest of these is Deuteronomy 8, which speaks of Israel being destroyed. Putting this passage in its immediate context, it comes after chapter 7, which contains the command to destroy the Canaanites with the danger of their own destruction if they do otherwise. Chapter 8 outlines the importance of remembering YHWH and our verses note the danger of not remembering him.

Immediately after this passage comes the warning to Israel in 9:4-6. In this passage, YHWH is pre-empting any misunderstanding by Israel that they somehow deserved the land, and that they were intrinsically more righteous than the nations that YHWH would drive out. It repeatedly rejects any idea that the land is given because of Israel's righteousness (vv. 4,5,6). Rather, the reason that the nations are being driven out is because of their wickedness (vv. 4,5), and the reason that Israel is being brought in is because of the patriarchal promises (v. 5). However, Israel need to be careful. They have just been warned in 8:19-20 that if they act like the Canaanites they will be treated like them. Now YHWH is telling them that they should not uncritically distinguish themselves from the Canaanites. ${ }^{30}$ The Canaanites acted wickedly, but Israel are stiff-necked (v. 6). Just to drive this home, Deuteronomy 9:7-10:11 remind Israel at length of the prime example of this stiff-necked behaviour - the sin of the Golden Calf. Israel broke the newly formed covenant by idolatry and were on the point of destruction averted by Moses' intercession.

Putting all of this together as part of Deuteronomy's sermonic exhortation to follow YHWH and his torah, the comparison becomes a

29 Num. 30 does not explicitly refer to acting like the Canaanites, but rather leaving them in the land. However, v. 52 links driving out the nations and destroying their religious paraphernalia, echoing the link in Deut. 7:2-5.

30 Cf. Christopher J. H. Wright, Deuteronomy (Peabody: Hendrickson, 1996), 133. 
strong warning. Israel must not follow the idolatry of the Canaanites (ch. 7), or they will be destroyed like the Canaanites (ch. 8). Israel are not intrinsically better than the Canaanites (9:4-6) and it is entirely possible for Israel to be idolatrous like the Canaanites, as they have already been with the Golden Calf $(9: 7-10: 11){ }^{31}$

To put it another way, the danger of the Canaanites is not only in their physical proximity to Israel (in the land, the idolaters Israel is most likely to encounter), but also in their moral proximity. Israel can become like them. The repeated warnings in Exodus to Deuteronomy testify to the very real possibility of this, as one does not repeatedly warn against something that is extremely unlikely. The one significant difference for the Bible between Israel and the Canaanites is Israel's covenant relationship with YHWH, based on the patriarchal promises, the reason why Israel have the land. If Israel break or ignore the covenant, then they will become, in effect, the Canaanites, and they will be treated like them. The Canaanites are a mirror to Israel of what they would be without YHWH.

\section{b. Post-Conquest Outworking}

Thus far, the focus has been the warnings in the divine commands before the conquest. The main mention of the Canaanites in the postconquest story of Israel in the land continues this theme of warning and example, as Israel and Judah are judged on their loyalty to YHWH and their keeping of the covenant.

Joshua 23 to Judges 3 forms a transitional point at the time of the conquest. In Joshua 23, after the conquest and allocation, Joshua warns the people in terms similar to the divine warnings. They are not to mix with the Canaanites or follow their gods (Josh. 23:7). If they do, the Canaanites will be snares and thorns to them and YHWH will destroy them from the land (23:12-13,15-16; cf. 24:20). Moving to Judges, chapter 1 notes the successes (vv. 4-18) and failures (vv. 19-36) of Israel in driving out the Canaanites. After this, in chapters 2 and 3 , Israel are reprimanded by YHWH for not driving out the nations, and told that YHWH will no longer drive them out: they will be adversaries

31 Moreover, the previously mentioned most negative portrayal of the Canaanites in Deut. 12:31 is a warning to Israel not to enquire about their gods (vv. 29-31). It is followed immediately by Deut. 13, which outlines the consequences of anyone in Israel following other gods or encouraging others to do so. They are to be put to kherem by the Israelites just like the Canaanites (13:2-18; cf. 17:2-7 (Israel); 7:2; 20:17 (Canaanites)). 
and snares for Israel (2:1-3), and a test for Israel both in terms of combat (3:1-2) and whether they would follow YHWH or not (2:21-23; 3:4). ${ }^{32}$ Chapter 3:5-6 summarises Israel's response to the test: they fail, marrying Canaanites and worshipping their gods. These passages surround the summary of Israel's behaviour in 2:6-19, which gives the pattern of the stories in Judges, linking the Canaanites to the cycles that Israel follow.

In the books of Kings, there is a repeated theme where the nation or its king is compared to the Canaanites. Rehoboam's Judah provoke YHWH to jealousy with their religious practices: 'they committed all the abominations of the nations that YHWH drove out before the people of Israel' (14:24b). This is an implicit warning to the new kingdom of Judah. They are doing what the nations did, and YHWH drove out the nations for this. ${ }^{33}$ A similar comparison is made with kings Ahab (1 Kgs 21:25-26) and Ahaz (2 Kgs 16:3), both of whom are notorious for importing foreign worship, and are described as going after idols (Ahab) and child sacrifice (Ahaz) like the nations. The detailed reason given for the destruction of the northern kingdom contains two such comparisons with the Canaanites (2 Kgs 17:8,11; cf. 1 Chr. 5:25-26).

Finally, there is the indictment of Manasseh that he led Judah astray 'to do more evil than the nations whom YHWH destroyed before the people of Israel' (2 Kgs 21:9; cf. 2 Chr. 33:9). ${ }^{34}$ Not only is Judah compared to the Canaanites (v. 2), but they are judged to be worse than them. (vv. 9,11). The description of Manasseh's evil emphasises this comparison. The focus is on religious practices (vv. 3-8), which resonate with the description of the Canaanite's sins, including the mention of child sacrifice (v. 6). ${ }^{35}$ The description of the temple contrasts its current profaned state as a home for idols (vv. 4a,5,7a)

32 Block suggests that YHwH's use of 'nation' (ג', goy) to describe both Israel (2:20) and the Canaanites (vv. 21,23) categorises them together even at this stage. Daniel I. Block, Judges, Ruth (Nashville: B\&H, 1999), 133.

33 This passage follows Jeroboam's reign with the focus on his golden calf idolatry (12:25-14:20). The judgement on Rehoboam shows that both kingdoms started with implicit warnings. Ian W. Provan, 1 and 2 Kings (Carlisle: Paternoster, 1995), 121.

34 In Chronicles, the exile is not announced under Manasseh, who receives an immediate response (2 Chr. 33:11-13). Instead, in $2 \mathrm{Chr}$. 36:14 there is a judgement comparing Zedekiah, the priests, and the people to the Canaanites, leading to the exile (vv. 15-21).

$352 \mathrm{Kgs}$ 21:6 uses many of the terms in Deut. 18:10-11 warning about the danger of Canaanite practices for which they were being driven out. V. 16 also includes Manasseh's shedding of innocent blood, but this is mentioned briefly after the details on his idolatry and the consequences of this. 
with its intended function as the symbol of YHWH's dwelling with his people, linked to the Davidic kingship and covenant and the wider covenantal relationship of YHWH and his people in which they received the land (vv. 4b,7b-8). This contrast emphasises Manasseh's utter rejection of the covenantal relationship with YHWH and the consequences of this. ${ }^{36}$ Judah under Manasseh have become equivalent to Samaria under Ahab and will be treated as such (v. 13) as YHWH rejects his inheritance and hands them over to their enemies (v. 14). ${ }^{37}$ By acting like (or worse than) the Canaanites, Judah have become like them and will be treated like them, just as Israel were before them. ${ }^{38}$

\section{c. Really 'Like the Nations'? Turner and Implications}

Comparing the post-conquest outworking to the warning in Deuteronomy 8:19-20 raises a seeming anomaly. It is clear that Israel have acted like the Canaanites. However, it is less clear that they have been treated just like them. They have been exiled, but Deuteronomy speaks about destruction, both for the Canaanites and for Israel.

In his recent study on Deuteronomy's theology of exile, Turner looks in detail at the meaning of 'destruction' in Deuteronomy. ${ }^{39} \mathrm{He}$ notes that when Deuteronomy speaks of exile it does not use the more common exile terminology גלה (glh) שלה (shvh). Instead, he argues that Deuteronomy uses the stronger Hebrew verbs שמד (shmd) and ('bd), which normally refer to destruction. He focuses on three key exile texts (Deut. 4:25-31; 27:58-68; 30:1-10), although he examines others as well. As an example, 4:25-31 warns against the consequences of idolatry. If Israel worship other gods (v. 25) then they will be destroyed from upon the land (v. 26, אבד and שמד - both verbs strengthened with infinitive absolutes). However, verse 27 then

\footnotetext{
36 As well as the contrast to David there is no mention of the Davidic promise mitigating YHWH's response as there had been in the past (1 Kgs 11:12-13; 15:4-5).

37 As well as the connection between the sins of Manasseh and Ahab (and the comparison in both cases with the Canaanites), one other canonical connection between them is their repentance (Manasseh in 2 Chr. 33:12-17; Ahab in $1 \mathrm{Kgs}$ 21:2729). Even the most idolatrous kings, comparable to the Canaanites, can repent before YHWH. That repentance may not remove all the consequences of their sin but it does have an effect. This nuances the image of warning, showing Israel how they could and should respond even when acting like the Canaanites. For more details on Ahab's repentance as a pointer for the reader see T. S. Hadjiev 'The King and the Reader: Hermeneutical Reflections on 1 Kings 20-21', TynBul 66.1 (2015), 63-74, esp. 71-74.

38 Cf. Peter J. Leithart, $1 \& 2$ Kings (London: SCM, 2006), 264.

39 Kenneth J. Turner, The Death of Deaths in the Death of Israel: Deuteronomy's Theology of Exile (Eugene: Wipf \& Stock, 2011).
} 
speaks of YHWH scattering them among the nations, few in number, qualifying and explaining the previous verse. If Israel had been completely wiped out, then there would be nobody to scatter. Moreover, verse 31 says that YHWH is a merciful God who will not abandon or destroy (שחת, shkht) them. ${ }^{40}$

Turner argues that Deuteronomy uses these verbs of destruction hyperbolically as part of a rhetorical strategy to explain theologically the consequences of exile for Israel. For the nation, exile means destruction, the death of the nation as a nation in the land. Therefore, restoration would mean resurrection, a new life out of death with a new covenant. $^{41}$

Turner's focus is primarily on Israel, although he briefly notes implications for the Canaanites. ${ }^{42}$ Expanding this understanding of 'destruction' in Deuteronomy would have significant consequences for the portrayal of Canaanites as warning. Israel are to be destroyed like the nations (8:19-20), and for Israel this means exile - the destruction of the nation as a nation in the land. Therefore, for the comparison to make sense, it suggests that when Deuteronomy speaks of the nations being 'destroyed' by YHWH or Israel, this should also be understood as the equivalent of exile, the nations being driven out and thus destroyed as nations in the land. We can note three specific consequences of this, which would cohere with the wider biblical portrayal.

First, this relates to the link between the Canaanites and the land. They are a danger to Israel because they are in the land. If they are no longer in the land, they are no longer a danger, at least no more so than other nations. They are also a warning to Israel that committing idolatry will lead to losing the land. The later history with its comparisons to the Canaanites shows that when Israel and Judah become as bad as (or worse than) the Canaanites, they also lose the land. The one difference is that Israel are returned to the land. However, this is due to YHWH rather than them (Ezek. 36:22-32).

40 For details on 4:25-31 see Turner, Death, 85-122.

41 Turner, Death, 225-31. This resurrection is most graphically illustrated in Ezekiel's vision of the valley of dry bones with accompanying interpretation (Ezek. 37:1-10,1114).

42 Turner, Death, 191-94. He considers the kherem command as a possible objection to his argument, but suggests that the command should be read hyperbolically for both Israel (7:26) and Canaan (7:2). Versluis, Command, argues against any metaphorical reading of kherem (45-68). He extends this to the wider commands to destroy the Canaanites (222-85). 
They do not deserve to return, just as they did not deserve the land in the first place (Deut. 9:4-6). ${ }^{43}$

Second, this would provide a way to read the seemingly different concepts of destruction and dispossession in the commands in Exodus to Deuteronomy. Israel is to ensure that the nations are 'destroyed' as functioning religious entities within the land. To do this does not require the death of every single Canaanite. Israel needs to do whatever is necessary to prevent the religious danger of the Canaanites, but not necessarily more than that.

Third, understanding the divine destruction commands hyperbolically would resonate with a hyperbolic reading of the conquest material in Joshua 9-12. Lawson Younger has shown that this material is very similar to other ancient Near Eastern conquest accounts that use hyperbole to describe victories as the slaughter of the enemy group. ${ }^{44}$ Thus, while at first glance the likes of 10:40 and 11:20 suggest that Israel wiped out every living Canaanite man, woman, and child, the allocation of land section starts with YHWH saying that much land still remains to be conquered (13:1). The allocation of land in chapters 13-19 includes the varying degrees of success of the different tribes in conquering these lands, including reference to Canaanites that survive in the land. ${ }^{45}$ Joshua $10-11$ is better understood as depicting stunningly successful raids that disable the key Canaanite military forces rather than wiping out entire nations. ${ }^{46}$

\section{d. A Prophetic Reference}

References to the Canaanites in the rest of the Old Testament do not easily fall into groups. In some cases, the word 'Canaanite' is probably referring to traders rather than to an ethnic group, and thus is not relevant for this investigation. ${ }^{47}$

43 G. McConville, Deuteronomy (Leicester: IVP, 2002), 182.

44 K. Lawson Younger Jr., Ancient Conquest Accounts: A Study in Ancient Near Eastern and Biblical History Writing (JSOTSup 98; Sheffield: Sheffield Adademic Press, 1990).

$4513: 13 ; 15: 63 ; 16: 10 ; 17: 12-13$. Later passages also note the survival of some of the Canaanites (2 Sam. 21:2; 24:7; 1 Kgs 9:20-21/2 Chr. 8:7).

46 The contrast should not be overdrawn. Destruction in the sense of dispossession with the accompanying battles would still have involved a significant number of Canaanite deaths, including, presumably, those of women and children.

47 For example, Isa. 23:8; Hos. 12:8-9; Zeph. 1:11; Job 40:30; Prov. 31:24. For more details on these and other prophetic and wisdom uses, see Lemche, Canaanites, 12350 . 
There is, however, one detailed prophetic use of Canaanites as warning in Ezekiel 16. Judah, represented by Jerusalem, personified as a young woman, is confronted with her unfaithfulness to her husband YHWH in a passage that is shocking and difficult for many readers due to the detailed sexual imagery and harsh treatment of the 'wife', Jerusalem. Another element that would be shocking to the original hearers is the family relationship with the Canaanites - Jerusalem was born in the land of the Canaanites to an Amorite father and a Hittite mother (v. 3, cf. 44-45), and her actions prove her to be a Canaanite, including child sacrifice (vv. 20-21,36). Her sisters are Samaria and Sodom, the latter arguably one of the worst Canaanite cities of all. (v. 46), and Jerusalem is judged to be worse than either of them (v. 51). ${ }^{48}$ Ezekiel uses this absolute association with the Canaanites as a stunning indictment, and thus a warning, to Jerusalem and Judah. ${ }^{49}$ Having said that, the passage ends with a positive image, albeit to demonstrate Jerusalem's disgrace further. YHWH will restore Samaria and Sodom as he makes an eternal covenant with Jerusalem. As Jerusalem is associated with them, so they are associated with Jerusalem - thus disgrace, but also hope for the Canaanite sisterhood of Samaria, Jerusalem, and Sodom..$^{50}$

\subsection{Summary}

Three images have been considered with regard to the portrayal of Canaanites as a whole in the Old Testament. ${ }^{51}$ The best image is

48 Whereas it would take roughly 400 years for the sin of the Amorites to be complete (Gen. 15:16) and thus lead to their destruction, Sodom and Gomorrah's evil is so great that they are destroyed within Abraham's lifetime. If Sodom makes the rest of the Canaanites look good, then Jerusalem makes Sodom look good (and thus how much more the rest of the Canaanites).

49 Cf. Daniel I. Block, The Book of Ezekiel Chapters 1-24 (Grand Rapids: Eerdmans, 1997), 474-75, 491, 506, 510.

50 Another prophetic future image that portrays the Canaanites differently is Zech. 14:21. While all of the non-Israelite nations will go to Jerusalem to worship YHWH (vv. 16-19), the vision ends by stating that 'there will no longer be a Canaanite in the house of YHWH of hosts'. If 'Canaanite' is taken in its ethnic sense rather than as 'trader' then in context this is not the exclusion of one specific nation, but rather the exclusion of 'Canaanite as danger'. In the Jerusalem that is 'holy to YHWH' there will be no idolatry as all the nations come. Whereas Ezek. 16 ends with a future association with the Canaanites, Zech. 14 ends with a future disassociation.

51 The New Testament does not mention the Canaanites as a whole. This lack of mention is not surprising given the focus beyond the land of Israel itself. Thus comparable warnings have a wider focus, for example against forming inappropriate relationships with unbelievers ( 2 Cor. 6:14-7:1) and destroying anything that causes 
'Canaanites as warning', as it combines 'Canaanites as sinners' and 'Canaanites as danger', and applies it to Israel as part of Israel's scripture. It also brings in the similarities between Israel and the Canaanites, both in terms of location and behaviour. Understanding 'destruction' as referring to destruction of a nation in the land shows a clear comparison between the acts and the treatment of both Israel and the Canaanites.

\section{Portrayal of Individual Canaanites}

The biblical portrayals of individual Canaanites occur largely in Genesis and Joshua as one might expect, being the stories of Israel in the land before and during the conquest when they would be most likely to encounter specific Canaanites.

The portrayal of these individuals is surprisingly different from the portrayal of the Canaanites as a whole, and often it is more positive. One way to understand this difference is to look at the different contexts and roles of the portrayals. The 'Canaanites as a whole' references come largely in two contexts: first, the pre-conquest divine commands in Exodus to Deuteronomy, where Israel are outside the land and not encountering any Canaanites; second, the post-conquest comparisons of the behaviour of kings and people to the memory of Canaanite behaviour. In both cases, the context is one where there was no or little actual interaction between Israel and the Canaanites. Therefore, they are known mainly as an undifferentiated group whose function is to be a warning to Israel of living without a relationship to YHWH and the consequences of that. In contrast, in Genesis and Joshua Israel were encountering individual Canaanites who could fulfil a number of different roles or functions for Israel, both bad and good. Moreover, the genre is different - warnings and comparisons are compared with narrative encounters.

\subsection{Genesis 14 and Melchizedek}

The first interaction with actual Canaanites in Genesis 14 gives various different portrayals of Canaanites, showing that they are not viewed as a homogenous mass. Abram is staying by the oaks of Mamre the

sin, once again hyperbolically in terms of removing one's own hand or eye (Mt. 5:29$30)$. 
Amorite and his brothers Eschol and Aner (v. 13). They are stated to be allies of Abram who help him to fight against the kings (v. 24), and there is no hint of censure of Abram for allying with Amorites. After the brief description of the battle, we encounter two Canaanite kings portrayed in contrasting ways.

Melchizedek (vv. 18-20) is described simply as king of Salem (or Jerusalem).$^{52}$ As such, he is presumably a Canaanite (more specifically Jebusite) king priest. He offers Abram royal hospitality (bread and wine) in his kingly role and blesses him in his role as priest of El Elyon (God Most High). Abram responds by giving him a tenth of everything, explicitly acknowledging Melchizedek as king and priest. ${ }^{53}$

In contrast, the king of Sodom offers no hospitality even in his words, brusquely telling Abram how to dispose of the plunder (v. 21). ${ }^{54}$ Abram refuses him by an oath to YHWH that is phrased almost exactly the same way as Melchizedek's invocation, simply adding 'YHWH' to the beginning (v. 22, cf. v. 19). This suggests that the God of Abram and the God of Melchizedek are the same. ${ }^{55}$ Thus, Melchizedek is (in some way) a worshipper of the true God and blesses Abram by him.

Melchizedek is mentioned again in Psalm 110 where YHWH swears that the psalmist's lord is 'a priest forever according to the order of Melchizedek' (v. 4). Melchizedek also features in detail in Hebrews chapters 5 and 7, where the Psalm 110 phrase is applied twice to Christ (5:6; 7:17). Christ is a 'priest forever according to the order of Melchizedek', the Canaanite king-priest. ${ }^{56}$

\footnotetext{
52 Salem is only used elsewhere in Ps. 76:3 [2], where it is paralleled with Zion, and it is generally associated with Jerusalem. Claus Westermann, Genesis 12-36: A Commentary (London: SPCK, 1985; trans. from German, 1981), 204.

53 Westermann, Genesis 12-36, 204.

54 Gordon J. Wenham, Genesis 1-15 (WBC 1; Dallas: Word, 1987), 318.

55 R. W. L. Moberly, The Old Testament of the Old Testament: Patriarchal Narratives and Mosaic Yahwism (Minneapolis: Augsburg Fortress, 1992), 72. Westermann, Genesis 12-36, 204 notes that El Elyon is only used elsewhere in Ps. 78:35, but Elyon alone is paralleled with YHWH and other divine names.

56 Hebrews 7:3 describes Melchizedek as 'without genealogy' and there is no suggestion in this passage that he is Canaanite. Nevertheless, the focus of the "without genealogy' is probably a contrast to Levitical/Aaronic genealogy. On this phrase see Gareth Lee Cockerill, The Epistle to the Hebrews (Grand Rapids: Eerdmans, 2012), 298-301.
} 


\subsection{Tamar and Other Genesis Encounters}

This varied portrayal of Canaanites continues in Genesis. The main focus of the encounters between patriarchs and Canaanites is either the acquisition of land or intermarriage, both linked to the patriarchal promises of land and descendants. ${ }^{57}$

- Abraham makes a deal with Ephron the Hittite to buy a burial plot (Gen. 23). The first acquisition of land in Canaan is peaceful (albeit costly).

- There is a brief negative mention of Esau's Hittite wives (26:34-35) which precedes the story of Jacob's theft of the blessing and being sent to Paddan-Aram to obtain a non-Canaanite wife (28:1-5).

- On his return, Jacob purchases land from Hamor the Hivite. This encounter starts peacefully (33:19-20), but descends into violence due to Shechem's rape of Dinah and the cunning and brutal response of Simeon and Levi (34:1-31; cf. 49:5-7).

The most detailed story concerning intermarriage is found in Genesis 38. Judah leaves his brothers to settle among the Canaanites and take a Canaanite wife, who provides him with three sons. However, the heroine of the chapter is another woman, Tamar, who struggles to fulfil her obligation to provide a son for her dead husband, in the face of opposition from Onan and Judah. In a story with several surprising twists, she manipulates Judah into impregnating her. When she is found to be pregnant and ordered, by Judah, to be burnt, she confronts him with the evidence of his paternity, leading him to acknowledge her as the righteous one rather than him (vv.24-26).

Tamar's background is not mentioned explicitly in the passage. However, the strong implication is that she is a Canaanite. Judah is living among them and has already taken one Canaanite as his wife (vv. 1-2), so he has no problems with Canaanite intermarriage. Given this background, one would expect a contrasting statement if Tamar was not Canaanite. However, not only is there no detailed story of seeking a wife from Aram as with Isaac and Jacob (Gen. 24; 28-31), but there is no mention of any relationship to the patriarchs.

57 This section draws on the discussion of Canaanite intermarriage in Genesis in William Ford, “'You shall not marry a Canaanite!": Endogamy, (Canaanite) Exogamy and Theology in Genesis 12-50' (unpublished paper, Tyndale Quadrennial, High Leigh, 2016). Cohn discusses this interaction in detail, albeit taking a more negative view of it. Robert L. Cohn, 'Negotiating with the Natives: Ancestors and Identity in Genesis', HTR 96.2 (2003), 147-66, esp. 151-58. 
If, therefore, as seems very likely, Tamar is Canaanite, this means that all of Judah's sons have Canaanite mothers, and the whole tribe of Judah is the result of Canaanite intermarriage. Moreover, not only is Tamar the Canaanite heroine of this story, but she and her sons have wider importance for the patriarchal promises. Her second-born, Perez, gains ascendancy over his brother in the Genesis pattern of supplanting the firstborn (38:27-30). This hint of importance is developed in the book of Ruth, another story of a righteous foreign woman seeking to fulfil the levirate, which concludes with a brief genealogy from Perez to David (Ruth 4:18-22).58

This genealogy is continued in the New Testament in Matthew 1, where Tamar the Canaanite is mentioned as an ancestress of Jesus (Matt. 1:3) She is one of only four women mentioned in Matthew's genealogy before Mary. These women are not the matriarchs, indeed most are not even Israelite in origin. The first, Tamar, is probably Canaanite, and the second is even more so - Rahab the prostitute from Jericho. Tamar is the last Canaanite that the children of Israel encounter in detail before they travel to Egypt. Rahab is the first Canaanite that they encounter in detail on their return. ${ }^{59}$

\subsection{Joshua Encounters - Rahab and the Gibeonites}

At first glance, Rahab the Canaanite prostitute would seem to embody all that is dangerous about the Canaanites. Yet in Joshua 2 she proactively sides with Israel, hiding the Israelites spies in defiance of her own king and at the risk of her own life. She explains her reasons in verses 9-11: she has heard of what YHWH has done for Israel in Egypt and Transjordan; she knows that YHWH has given the land to Israel; and she confesses that 'YHWH your God is God in heaven above and on the earth below'. This is the greatest confession of YHWH in the book of Joshua. Ironically, it is given not by an Israelite but by a Canaanite. Her response to her understanding of this God is to side with him and his people. As a result, she and her family are explicitly

58 Tamar and Perez are also used as a blessing in Ruth 4:12.

59 Israel do, of course, encounter the various Canaanite kings who oppose Israel in Numbers 21 and Deuteronomy 2-3. This continues into Joshua, where we read on several occasions of the response of the Canaanite kings to Israel and YHWH's acts (Josh. 5:1; 9:1-2; 10:1-5; 11:1-5). However, the Canaanite kings in Joshua are not the focus of the conquest stories. Instead the focus is on two smaller groups of Canaanites: Rahab and her family (Josh. 2, 6) and the Gibeonites (Josh. 9-10). 
spared from Jericho's destruction, and live within Israel 'to this day' (Josh. 6:17,22-25).

There is one other group who act in a similar way to Rahab. The Hivites of Gibeon do not ally with the other Canaanite kings against Israel (Josh. 9:1-2), but rather seek to side with Israel, albeit by deception about their location (vv. 3-13). As a result, Israel make a covenant of peace with them and uphold it, even when they realise the Gibeonites' true origin (9:14-10:15). The Gibeonites give similar reasons to Rahab for siding with Israel and their God: they had heard of YHWH's acts in Egypt and Transjordan and they knew he had given the land to Israel $(9: 9-10,24)$. Because of their deception, they are made hewers of wood and drawers of water, but for YHWH's shrine. Like Rahab, in effect, they become part of Israel.

In both cases, Canaanites come to Israel seeking to ally themselves with Israel because of their God, in effect, seeking to side with this God. In both cases they are accepted. These are the only two examples of Canaanites who seek to side with Israel in the book of Joshua. Therefore we can say that in the conquest, any Canaanite who seeks to side with Israel and YHWH is accepted. The Canaanites are not doomed to destruction. All of them have heard the same things about YHWH. Their treatment depends upon how they respond to him. ${ }^{60}$

This is the inverse of Israel's position. Israel, YHWH's chosen people, must not follow the gods of the Canaanites. If they do, they will become, in effect, Canaanites, and be treated like them. The story of Achan in Joshua 7 is another example of this. Achan disobeys YHWH's command, associating himself with Jericho and its plunder. As a result, he becomes like Jericho, and is eliminated from Israel. The Israelite is treated like the Canaanites. However, Rahab and the Gibeonites show the converse of this: Canaanites who side with YHWH can become like Israel, and be treated like them. The placement of Achan between Rahab and the Gibeonites, and other literary links between these stories, makes this contrast explicit. Israelites can

60 The Canaanite kings hear and respond by opposing Israel and thus YHWH, with the result that they are destroyed. Rahab and the Gibeonites hear and respond by seeking to side with Israel and thus YHWH, with the result that they are spared. Ford, 'Gibeonites', 213-16. 
become Canaanites and Canaanites can become Israelites. What matters in the end is not ethnicity, but one's attitude to YHWH. ${ }^{61}$

Thus, even Canaanites, those under sentence of destruction, can avoid that sentence. Those who are a warning to Israel of the dangers of idolatry can also be an example to Israel of confessing the one true God in word and deed. Rahab herself is mentioned in two other places beyond the Matthew 1 genealogy, in both places as an example of lived-out faith. She is the final detailed example given in the great Hebrews 11 portrayal of living 'by faith' (v. 31). ${ }^{62}$ She is also mentioned in James 2 as one of two examples of those who lived by faith (v. 25), the other example being Abraham (vv. 21-23). ${ }^{63}$ It is not surprising that the rabbis and the early church used Rahab as an example of the ideal proselyte and gentile convert respectively. ${ }^{64}$

\subsection{Post-Conquest Encounters}

After the conquest, it is not surprising that there is little mention of encounters with individual Canaanites. There are a few, such as the tragic figure of Uriah the Hittite, the Canaanite who acts more righteously than the Israelite king David, reminding us of the righteous Canaanite Tamar and the unrighteous Israelite Judah. Sadly, unlike Tamar, this time, the death decreed by the guilty man is not stopped. Interestingly, Uriah's name also appears in Matthew's genealogy: 'David was the father of Solomon by the wife of Uriah' (Matt. 1:6). Ruth is the only one of the four women mentioned in the genealogy not linked to the Canaanites, and even she is not Israelite. Ethnicity is unlikely to be the reason for their inclusion. ${ }^{65}$ However, it clearly does not exclude it.

61 Hawk and Earl show how the book of Joshua (including Rahab, Achan, and the Gibeonites) nuances the concept of Israelite identity. L. Daniel Hawk, Joshua (Berit Olam; Collegeville: The Liturgical Press, 2000; Earl, Reading.

62 She is contrasted with the 'disobedient' (other Canaanites). Response, not ethnicity, is the key factor.

63 The Gibeonites do not feature in the New Testament but they are mentioned in 2 Sam. 21. YHwH's anger at Saul's attempt to destroy them shows that they were still meant to be treated like Israel, rather than Canaanites.

64 Judith Baskin, 'The Rabbinic Transformations of Rahab the Harlot', Notre Dame English Journal,11.2 (April 1979), 141-57.

65 W. D. Davies and Dale C. Allison, A Critical and Exegetical Commentary on the Gospel According to Saint Matthew (vol. 1; Edinburgh: T\&T Clark, 1988), 170-72. 
As well as these mentions of Old Testament Canaanites, there is one New Testament encounter with an individual Canaanite. ${ }^{66}$ In Matthew 15:21-28 Jesus encounters a Canaanite woman who begs him to exorcise her daughter (v. 22). ${ }^{67}$ While Jesus' initial words towards her are negative (vv. 24,26), arguably the surprise for the original readers would be his subsequent commendation of her faith (v. 28). As with Rahab, a Canaanite woman shows faith in the God of Israel in her actions and receives what she asks for.

\subsection{Summary}

Looking back at the portrayal of individual Canaanites in the Bible, the most noticeable thing is how positive that portrayal is. In light of the portrayal of the Canaanites as a whole, one might expect negative portrayals, to flesh out the idea of Canaanites as warning or danger. However, the majority of portrayals are not like this. Not every portrayal is positive, but not every portrayal of Israelites is positive, to say the least. Moreover, within these portrayals are some that are very positive: Melchizedek, Tamar, Rahab, and the Canaanite woman. These are not warnings of how not to live, examples of the dangers of turning away from God. Rather, they are examples of honouring God that should be followed. Instead of being a danger to God's salvation as expressed in the patriarchal promises, they contribute to it. Jesus is a priest in the order of Melchizedek and a descendant of Tamar and Rahab. Interestingly, it is this positive image of the Canaanites that is present in the New Testament, not the negative portrayal of the Canaanites as a whole.

\section{Conclusion - 'Canaanites as Challenge'}

In conclusion, combining the biblical portrayals of Canaanites as a whole and as individuals requires a nuancing of the image of 'Canaanites as warning'. This is the most appropriate image for the Old Testament portrayal of Canaanites as a whole, which is negative, albeit not as much as might initially be thought.

66 For more detail on this passage and Canaanites in Matthew, see Glenna S. Jackson, Have Mercy on Me: The Story of the Canaanite Woman in Matthew 15:21-18. (JSNTSup 228; Sheffield: Sheffield Academic Press, 2002).

67 Mark describes her as 'Syro-Phoenician' (Mk. 7:26). 
- They are sinners, but not the worst sinners ever. Rather, they worship other gods and thus engage in practices that are abhorrent to YHWH, as others do. The difference is that the other nations are not in the land and thus not such a danger to Israel.

- They are a danger to Israel, but they do not therefore need to be demonised as something completely and negatively different. The warning given before the conquest is that Israel can be quite similar to them, as the later stories show. Specifically, they are a warning to Israel of the consequences of idolatry. If Israel act like them, they will be treated like them, by being destroyed as a nation in the land.

However, adding the more positive portrayal of individual Canaanites nuances the negative image still further. The Canaanites are not simply a race doomed to destruction, even the lesser destruction of being destroyed in the land. The examples of individual Canaanites demonstrate that any who choose to respond positively to the God of Israel will be treated like Israel. In some cases, this is even to the extent of being explicitly included in the patriarchal promises and held up as examples of faith.

Therefore, an image to summarise the overall biblical portrayal needs to be one that confronts Israel in both negative and positive ways: 'Canaanites as challenge'. ${ }^{68}$ The portrayal of the Canaanites as a whole is the negative challenge: the warning to Israel. This is what Israel would be like without their relationship to YHWH. Israel can become like them and be treated like them. The portrayal of the Canaanites as individuals contains the positive challenge. There are some Canaanites whose response to God is an inspiration, an example to be followed.

In both cases, the key factor is how people respond to God, be they Israelite or Canaanite, believer or unbeliever, and this resonates with the wider biblical message. On the one hand is the requirement of loyalty to God: 'You shall love YHWH your God with all your heart, soul and strength'; 'you shall have no other gods before me'. On the other hand is the hope for all, whoever they are: 'everyone who calls on the name of YHWH shall be saved', even Canaanites.

68 This challenge is different from, albeit related to, the concept of the challenge of the Canaanites for the reader of scripture with which this article started. While that challenge remains, this article has questioned whether the portrayal of the Canaanites and how God deals with them is so different from the portrayal of God's wider dealings with humanity, and Israel in particular. 